\title{
Peroxidase Isozymes and Proline Content In Relation To Salinity Tolerance in Stevia Plant \\ Amira khatab 1
}

\begin{abstract}
Stevia (Stevia rebaudiana) plant is an herbaceous perennial used normally as a natural herbal sweetener .Stevia leaves contain several chemicals called glycosides. These glycosides collectively give 100 to 300 times the sweetness of sucrose and are extracted and refined from plants without chemical or enzymatic modifications. The two main glycosides are Stevioside (traditionally $5-10 \%$ of the dry weight of leaves) and Rebaudioside $A$ (2-4\%). These glycosides are the sweetest compounds. There are also other related compound including RebaudiosideC (1$2 \%$ ) and Duclosid $A$ and $C$ as well as minor glycosides including flavonoid glycosides; coumarins; cinnamic acids; phenylpropanoids and some essential oils.
\end{abstract}

This work aims at investigating the role of isozyme variations and proline content in selection and breeding program for salinity tolerance. To achieve such a purpose four landraces of stevia were kindly obtained from the Institute of Sugar Crops and different salinity stresses were conducted.

However, proline acts as a compatible cytoplasmic solute, balancing an accumulation of salts outside of the cytoplasm. Proline levels in salt-shocked leaves, decreased to near control levels within $\mathbf{2 4}$ hours of relief of stress.

The data observed showed that differential gene expression and recommend the use of physio-genetical biomarkers as useful tool to identify the salinity tolerant genome.

\section{INTRODUCTION}

This work aims at investigating the role of peroxides isozymes and proline content in relation to salinity tolerance. Random amplified polymorphic DNA RAPD- PCR technique was used to study genomic differences .To achieve such a purpose, four genotypes were used. they were cultivated and tow concentrations of $\mathrm{NaCl}$ were applied (1000 \&1500 ppm). Detection of proline content before and after treatments for one and two months was carried out. RAPD - PCR based technique was conducted before as well as after treatment.

There have been considerable numbers of researches that report upon the use of isozymes as useful markers in genetic studies (Guan et al., 1990.)

Isozymes had been defined by (Shaw, 1969), as multiple forms of enzymes in the same organism and having similar or identical catalytic activity. The primaries are distinctly different molecules, and are presumably produced from different genetic sites, while the secondary isozymes results frome alteration in the structure of single polypeptide chain in vitro and many of these are artifact. The primary isozymes are only ones, which have biological significance. Weising et al., (1995); Garcia-Carreio \& Ochoa O. (1991) and TayefiNasrabadi et al., (2011).

Salinity is a major abiotic stress and is likely to increase in severity as a consequence of global warming Amira Khattab (2001,2008 and2014 a,b). Three primary components determine salinity tolerance (ST): osmotic tolerance, $\mathrm{Na}+$ exclusion and tissue tolerance. All three components are important, but contribute differently to overall ST. (Sherif 1999, Sherif et al 2007, ElIskandarani et al., 2008., Khosravinejad et a ., 2009, Kapoor and Srivastava (2010), Jamil et al., 2012., Radi et al., 2013 and Zeng et al., 2013). In order to learn more about the genetics of and genes controlling ST, two major studies need to be undertaken: firstly, screening and identification of the most appropriate accessions, lines or genotypes for further crossings; and secondly, identification of potential candidate genes using mapping populations and QTL analysis. This two step approaches is referred to as 'Forward Genetics', employing the classical methods of screening, genetic analysis and molecular mapping. They reported that wild relatives of wheat from the genus Triticum have much greater variation in $\mathrm{Na}+$ exclusion and $\mathrm{ST}$ compared to cultivated wheats. In contrast, cultivated durum and bread wheats have very little variability in these traits (Munns et al. 2000, Mukeshwar et al ,. 2014 and Ashraf and Harrisb (2004). This is mainly related to the erosion of genetic diversity through a consequence of two 'bottlenecks' of gene pool exploitation in the development of cultivated wheat: firstly, between two diploid species, progenitors of the A and B genomes, and, secondly, between the tetraploid progenitor and a third diploid species, the progenitor of the D genome (Huang et al. 2002; Dvorak \&Akhunov 2005). The domestication of tetraploid durum wheat and, later, bread wheat, particularly through the modern agricultural practices of pure breeding, resulted in a

\footnotetext{
${ }^{1}$ Faculty of Education,Majmaah University, kingdom of

Saudi Arabia and Institute of Graduate Studies \& Research,

Alexandria University,Egypt

Received August 18, 2015, Accepted August 25, 2015
} 
further loss of genetic diversity (Nevo 2004and Sadeghi 2009).

\section{MATERIALS AND METHODS}

Random Amplified Polymorphic DNA (RAPD) technique:

1- DNA extraction Procedure for total genomic of Stevia according to manufacturer protocol of Omega Co. (USA.LMt.):

1. To $100 \mathrm{mg}$ powdered leaf of ten olive cultivars which grounded in liquid nitrogen add $550 \mu \mathrm{L}$ of lysis buffer solution were added, shacked gently, incubated for $30 \mathrm{~min}$ on ice, and centrifuged at 1200 rpm for $10 \mathrm{~min}$ at $4^{\circ} \mathrm{C}$.

2. Supernatant was Removed (tissues waste), $1 \mathrm{ml}$ lysis buffer was added, the pellet was resuspend, and centrifuged for $10 \mathrm{~min}$ at $4^{\circ} \mathrm{C}(1200 \mathrm{rpm})$.

3. Supernatant was Removed (tissues waste), $0.5 \mathrm{ml} \mathrm{SE}$ buffer was added, the pellet was resuspend, followed by centrifugation for 10 minutes at $4{ }^{\circ} \mathrm{C}$ (1200 rpm).

4. Supernatant was Removed (tissues waste). (It is possible to store the pellet at $-80^{\circ} \mathrm{C}$. Centrifugation at $1200 \mathrm{rpm}$ for $10 \mathrm{~min}$ at $4^{\circ} \mathrm{C}$. The supernatant was Removed and the pellet was freezed). $1 \mathrm{ml} \mathrm{SE}$ buffer was added and the pellet was resuspend, 40 $\mu \mathrm{l}$ proteinase $\mathrm{K}(10 \mathrm{mg} / \mathrm{ml})$ was added and $250 \mu \mathrm{l}$ $20 \%$ SDS, shacked gently, and incubated overnight at $37^{\circ} \mathrm{C}$ in a water bath.

5. A $5 \mathrm{ml} \mathrm{SE-buffer} \mathrm{was} \mathrm{added} \mathrm{and} 10 \mathrm{ml}$ phenol shaked by hand for $10 \mathrm{~min}$, and centrifuged at 3000 rpm for 5 min at $10^{\circ} \mathrm{C}$.

6. The supernatant was transferred into a new tube, $1 \mathrm{ml}$ phenol/chloroform/ isoamyl alcohol (25:24:1) was added, shacked by hand for $10 \mathrm{~min}$, and centrifuged at $3000 \mathrm{rpm}$ for $5 \mathrm{~min}$ at $10^{\circ} \mathrm{C}$.

7. the supernatant Again was transferred into a new tube, $1 \mathrm{ml}$ chloroform/ isoamylalcohol (24:1) was added, shake by hand for $10 \mathrm{~min}$, and centrifuged at $3000 \mathrm{rpm}$ for $5 \mathrm{~min}$ at $10^{\circ} \mathrm{C}$.

8. The supernatant was transferred into a new tube; 100 $\mu 13 \mathrm{M}$ sodium acetate $(\mathrm{pH}$ 5.2) was added and 10 $\mathrm{ml}$ isopropanol, shacked gently until the DNA precipitated, use a glass pipette, make a hook over a Bunsen burner, and capture the DNA.

9. The DNA was washed in $70 \%$ ethanol and dissolved the DNA in $0.1 \mathrm{ml}$ TE-buffer overnight at $4^{\circ} \mathrm{C}$ on a rotating shaker. (If the DNA is not dissolved leave it longer at $4^{\circ} \mathrm{C}$ on the rotating shaker).

\section{2- Preparation of the PCR master mixture:}

Preparation of the amplification reaction was done under the biosafety cabinet in a separate room rather than that in which the amplification and the extraction were done. In Eppindorf tube, RAPD analysis was performed using arbitary decamer primers procured from Pharmacia Biotech. (Bioligo Inc, Korea) (Table 2). The components of the PCR were prepared as a master mix containing the reagents needed to amplify the required number of samples as well as positive and negative control (Table, 5) then $5 \mu \mathrm{l}(25 \mathrm{ng})$ of the DNA were added in the PCR tubes and $1.0 \mu \mathrm{l}$ of random primer was added (random primer listed in table). Finally, $20 \mu 1$ of the master mix were dispensed in it, to reach $25 \mu 1$ as a final volume of the reaction.

Table 1. Sequences of ten random primers selected in the present study

\begin{tabular}{ccc}
\hline Primer & $\begin{array}{c}\mathbf{\%} \\
\text { GC }\end{array}$ & Nucleotide Sequence 5' to 3' \\
\hline OPG-05/0.88 & 60 & CTGAGACGGA \\
\hline OPN-11/2.22 & 60 & ATCCGAGTGT \\
\hline OPV-08/1.05 & 70 & GGACGGCGTT \\
\hline OPS-19/1.34 & 60 & GAGTCAGCAG \\
\hline OPK-01/0.86 & 60 & CATTCGAGCC \\
\hline
\end{tabular}

\section{3- RAPD -PCR amplification:}

Total genomic DNA was amplified through GeneAmp Polymerase Chain Reaction (PCR) system cycler. PCR for amplified genomic DNA was carried out. The reaction consists of 40 cycles; each cycle consisted of denaturation at $94^{\circ} \mathrm{C}$ for $30 \mathrm{sec}$ followed by annealing at $30^{\circ} \mathrm{C}$ for $30 \mathrm{sec}$ and extension at $72^{\circ} \mathrm{C}$ for $30 \mathrm{sec}$. There was an initial delay for $15 \mathrm{~min}$ at $95^{\circ} \mathrm{C}$ at the beginning of the first cycle and 10 min delay at $72^{\circ} \mathrm{C}$ at the end of the last cycle as a post extension step (N.M. Lopera-Barrero et al., 2008) (Figure, ). The product was stored at $-20^{\circ} \mathrm{C}$ or $4^{\circ} \mathrm{C}$.

\section{4- Agarose gel electrophoresis and detection of the amplification products:}

$1.5 \%$ agarose solution was prepared by adding $0.75 \mathrm{~g}$ agarose to $50 \mathrm{ml}$ of $1 \mathrm{x}$ TBE electrophoresis buffer in $50 \mathrm{ml}$ flask. Heating in a microwave oven then dissolved the agarose. The agarose was cooled in $50^{\circ} \mathrm{C}$. A comb was inserted in electrophoresis bed and the agarose was poured in it. Great care should be taken during pouring of the agarose to avoid bubbles formation. The gel solidified within $15 \mathrm{~min}$ and became cloudy, the electrophoresis apparatus was filled with the electrophoresis buffer and the comb was removed creating 6 or 10 wells for sample application. Electrodes were connected to the power supply and the later was turned on. It was adjusted at 80 Volts for $100 \mathrm{~min}$. The gel was removed from its bed and transferred to the gel staining tray for staining with Ethidium bromide for 30 min followed by 20 min distain in distilled water. 
Table 2. Master Mix component for PCR reactions.

\begin{tabular}{lcc}
\hline Master Mix component & Amount & Final concentration \\
\hline Sterile nuclease free water & $17.8 \mu \mathrm{l}$ & \\
\hline 10x Taq buffer & $2.5 \mu \mathrm{l}$ & $1.0 \mathrm{x}$ \\
\hline 4mM PCR nucleotide mix & $2.5 \mu \mathrm{l}$ & $0.2 \mathrm{mM}$ \\
\hline Primer $(5 \mathrm{pmol} / \mu \mathrm{l})$ & $1.0 \mu \mathrm{l}$ & $5.0 \mathrm{pmol}$ \\
\hline Taq DNA polymerase $(5 \mathrm{u} / \mu \mathrm{l})$ & $0.2 \mu \mathrm{l}$ & $1.0 \mathrm{u}$ \\
\hline DNA extracted sample $(50 \mathrm{ng} / \mu \mathrm{l})$ & $1.0 \mu \mathrm{l}$ & $25.0 \mathrm{ng}$ \\
\hline Total & $25.0 \mu \mathrm{l}$ & \\
\hline
\end{tabular}

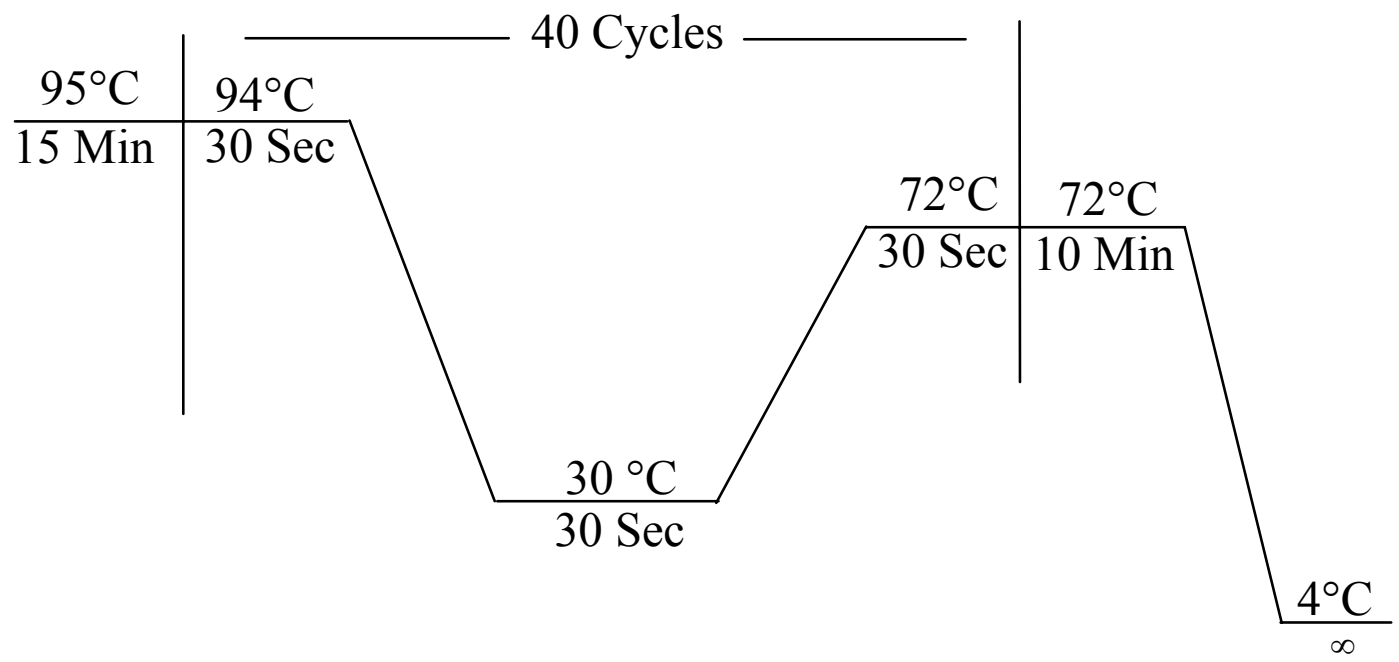

\section{Figure 2. Random Amplified Polymorphic DNA (RAPD) program for amplification of four different genotypes of stevia}

\section{5- Data analysis:}

Obtained amplified bands were recorded as 0,1 for absence and presence respectively through totalalb software analysis (www.totalalb.com. Ver.1.0) .

\section{RESULTS AND DISCUSSION}

Three factors are required for the effective implementation of molecular markers in breeding programes: (1) the availability of "users-friendly "markers (cheap, easy and reliable); (2) the validation of markers across different genetic background; and (3) the possibility of implementation them within a breeding program. (Seehy and Amira Khattab 2011., Amira Khattab \& Seehy 2013 and Mukeshwar\& Chikara (2014).

\section{A- Phylogenetic analysis:}

Obtaining bands from RAPD fingerprinting technique was represented as 0,1 for absence and presence band, respectively. Then, phylogenetic tree was constructed through PAST software analysis to detect genetic similarity among cultivars under study.

\section{B- Random amplified polymorphic DNA (RAPD) technique:}

The PCR technique has proved to be a powerful tool for the identification of polymorphism in cereals. Using wheat, barley, rye and wheat - barley addition lines, weining and langridge (1991) detected polymorphism using conserved and semi-random primers. With different combinations of primers, they were able to detect both inter-and intra specific diversity. Williams et al., (1990) reported that polymorphism between individuals can arise through; nucleotide change that prevent amplification by introducing a mismatch at one priming site; deletion of priming site; insertions that render priming sites too distant to support amplification ; and insertions or deletion that change the size of the amplified product.

In this investigation, Random amplified polymorphic DNA (RAPD) technique was performed to 
detect the differences among four stevia land races species through four arbitrary primers mentioned in materials and Methods. The numbers and sizes of genomic bands and Polymorphic bands resulted from applying those five primers with four stevia landraces are shown in Photograph ( ), Figure ( ) and Table ( ). According to Random amplified polymorphic DNA (RAPD) data, 14, 7, 19 and 14 polymorphism percentages were recorded for first, second, third, and fourth random primers. High similarity relation was detecting among genotyps under study as results of polymorphism percentage decreasing. To distinguish variation among genotypes under study, fifth primer with $19 \%$ of polymorphism was recommended. High similarity percentage among four stevia genotypes was founded through applying third random primer.

\section{C-Proline content:}

Table (1) shows proline content before as well as after treatment for two periods one, tow month's $\mu \mathrm{g} / \mathrm{g}$ dry leaves.

The data obtained from these tables $(3,4)$ shows that genotypes $(1,4)$ were proven to be higher in proline content at the tow tasted concentration of sodium chloride. This results, however gave a strong evidence that these tow genotypes might be used in selection and breeding program for salinity tolerance.

Table 3. Proline content $\mu \mathrm{g} / \mathrm{g}$ dry leaves treatment with 1000 ppm

\begin{tabular}{cccc}
\hline Genotype & Before treatment & after one month & after two months \\
\hline 1 & 18 & 30 & 62 \\
\hline 2 & 20 & 28 & 43 \\
\hline 3 & 16 & 22 & 30 \\
\hline
\end{tabular}

Table 4. Proline content $\mu \mathrm{g} / \mathrm{g}$ dry leaves treatment with 1500 ppm

\begin{tabular}{cccc}
\hline Genotype & Before treatment & after one month & after two months \\
\hline 1 & 18 & 36 & 84 \\
\hline 2 & 20 & 48 & 52 \\
\hline 3 & 16 & 50 & 66 \\
\hline 4 & 30 & 62 & 104 \\
\hline
\end{tabular}

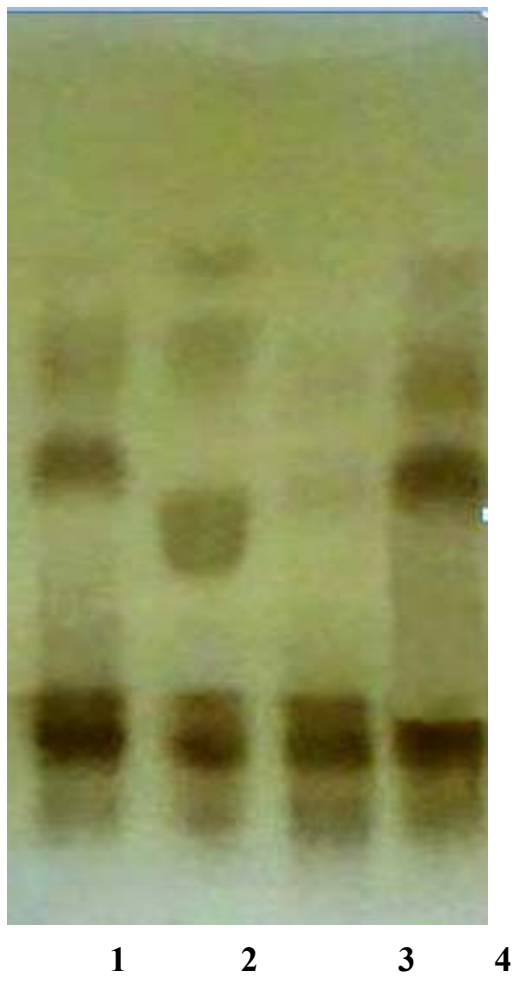

b

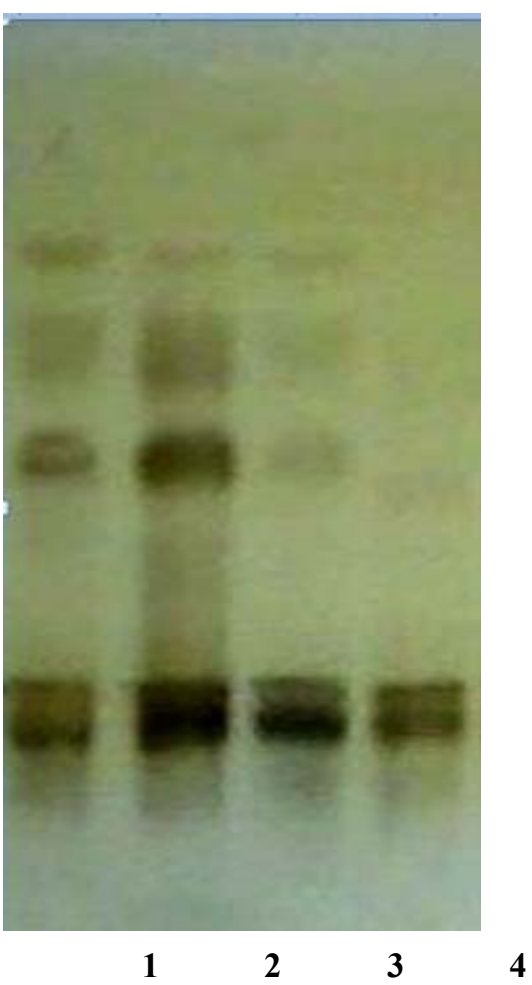


Figure 3. Photographs of peroxidase isozymes patterns for four stevia genotypes.a- after one month. b- after two months

Table 3. Illustrates Random Amplified Polymorphic DNA (RAPD)

\begin{tabular}{lcccc}
\hline Primer & $\begin{array}{c}\text { Total amplified } \\
\text { bands }\end{array}$ & $\begin{array}{c}\text { Polymorphic } \\
\text { bands }\end{array}$ & $\begin{array}{c}\text { Monomorphic } \\
\text { bands }\end{array}$ & $\begin{array}{c}\text { Polymorphic } \\
\text { percentage }\end{array}$ \\
\hline 1 & 74 & 19 & 55 & 26 \\
\hline 2 & 56 & 17 & 39 & 30 \\
\hline 3 & 56 & 16 & 40 & 28 \\
\hline 4 & 34 & 11 & 23 & $\mathbf{3 2}$ \\
\hline 5 & 33 & 8 & 25 & 24 \\
\hline
\end{tabular}

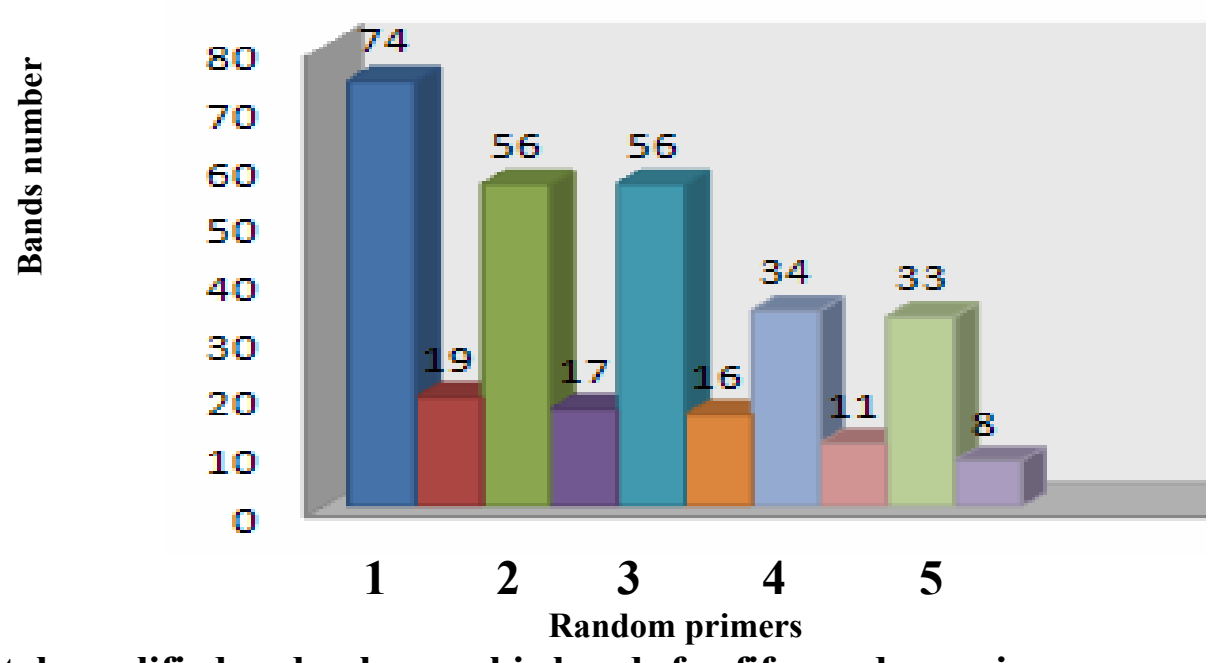

Figure 2. Total amplified and polymorphic bands for fife random primers screened four stevia genotypes

The present study indicated that RAPD markers, combined with isozymes, could be used to identify molecular markers linked to salinity tolerance and draught .Once these markers are identified, they can be used in breeding programs, as a selection tool in early generation.

\section{REFERENCES}

Amira, M. E. Khattab., (2001). MSc "Cytogenetical Studies on Sugarbeet"

Alexandria University, Faculty of Agriculture, Dept. of Genetics, Alexandria, Egypt.

Amira, M. E. Khattab .(2008). PhD (Genetics)"Application of Data Mining Techniques for Salinity Tolerance Genes Identification in Rice (Oryza sativa, L.) ".Alexandria University, Faculty of Agriculture, Saba Basha, Dept. of Genetics, Alexandria, Egypt.

Amira, M. E. Khattab. (2014 a): Assessment of Anti: Clastogenic and Carcinogenic Activity of Roselle (Hibiscus sabdariffa) Extract by Employing a Variety of Short-term Genotoxic Bioassays". Egypt. J of Genet. \& Cytology .43(2).
Amira, M. E. Khattab. (2014 b):Clastogenic and Mutagenic Effect Induced by Some Fast Foods". J. Adv. Agri. Res. 19(1): 100- 116.

Amira, M. E. Khattab, M. A. Seehy. (2013):Jojoba Leaf Extract Induced Nematocide Effect Upon Meloidgyne incognita" Alex. Science Exchange J. 34 (2): 255- 262.

Amira,M.E.Khattab, M. El-Zaidy and A.R.Doaigey. (2012): Cytogenetical and Biochemical Evaluation of Different Genotypes of Stevia Plants Used as a Natural Sweetener" J.Agric.Chem. and Biotechn., Mansoura Univ. 3(7):187193.

Dvorak J., Akhunov E.D. (2005): Tempos of gene locus Euphytica,

Effects of Salt Stress on the Growth, Physiological Responses, and Glycoside Contents of Stevia rebaudiana Bertoni. $J$. Agric. Food Chem., 2013, 61 (24), pp 5720-5726.

El-Iskandarani,M. A., A. S. Soliman, H. M. El-Wakil and Amira M. E. Khattab.(2008): Database Mining to Identify Salinity Tolerance Genes in Rice (Oryza sativa, L.)"J.Adv. Agri. Res. 13(2): 205- 229.

Garcia-Carreio F. L. \& I. L. Ochoa O. (1991): the effect of saline stress on peroxidase activity in the mezquite 
(Prosopis articulata) leaf. Journal of Arid environments (1991) 20: 313-319

Guan, G.P.;Abe and Y.Shimamoto (1990): Effects of gibberellic acid and abscisic acid on bolting of sugar beet (Beta vulgaris L.)Seedlings . Proceedings of the Japanese Society of sugar beet Technologists. 32:1-6.

H. Tayefi-Nasrabadi, G. Dehghan, B. Daeihassani , A. Movafegi and A. Samadi.(2011): Some biochemical properties of guaiacol peroxidases as modified by salt stress in leaves of salt-tolerant and salt-sensitive safflower (Carthamus tinctorius L.cv.) cultivars. African Journal of Biotechnology Vol. 10 (5), pp. 751-763, 31 January, 2011.

Huang S., Sirikhachornkit A., Su X., Faris J., GillIn: Henry R. 2002(ed.): Diversity and Evolution of kinase of the Triticum/Aegilops complex M.Sc. (Agri.) Thesis, University of Agricultural Sciences.

Jamil M, Bashir S, Anwar S, Bibi S, Bangash A, et al. (2012): Effect of salinity on physiological and biochemical characteristics of different varieties

Jianwei Zeng, Aimeng Chen, Dandan Li , Bin Yi , and Wei $\mathrm{Wu}(2013)$ :

Effects of Salt Stress on the Growth, Physiological Responses, and Glycoside Contents of Stevia rebaudiana Bertoni. J. Agric. Food Chem., 2013, 61 (24), pp 5720-5726

Kapoor K, Srivastava A (2010): Assessment of salinity tolerance of Vinga mungo var. Pu-19 using ex vitro and in vitro methods. Asian J Biotechnol2: 73-85.

Khosravinejad F, Heydari R, Farboodnia T (2009) Effect of salinity on organic solutes contents in barley. Pak J Biol Sci 12: 158-162.

M. Ashraf and P.J.C. Harrisb (2004). Potential biochemical indicators of salinity tolerance in plants. Plant Science Volume 166, Issue 1, January 2004, Pages 3-16.

Mukeshwar Pandey and Surendra K. Chikara (2014) : In vitro Regeneration and Effct of Abiotic Stress on Physiology and Biochemical Content of Stevia Rebaudiana 'Bertoni'. Journal of Plant Science \& Research. Volume 1, Issue 3 - 2014 : 1-9.

Munns R., Hore R.A., James R.A., Rebetzke G.J.Nevo E. (2004): Genomic diversity in nature and domestication. Northwest of Iran based on ISSR molecular markers. Int. J.of durum wheat. Australian Journal of Agriculturalof the National Academy of Sciences of the Pakistan.
Nevo E. (2004): Genomic diversity in nature and domestication. Northwest of Iran based on ISSR molecular markers. Int. J. of durum wheat. Australian Journal of Agricultural of the National Academy of Sciences of the Pakistan. of rice.Pak J Bot 44: 7-13.

Radi, A.A., Farghaly, F.A., and Hamada, A.M. (2013) Physiological and biochemical responses of salt-tolerant and salt-sensitive wheat and bean cultivars to salinity. Journal of Biology and Earth Science, 3(1), 72-88.

Sadeghi, H. (2009) Effects of different levels of sodium chloride on yield and chemical composition in two barley cultivars. Americal Eurasian Journal of Sustainable Agriculture. 3(3), 314-320.

Seehy M. A. and Amira M. E.Khattab(2011): Differential Gene Function and Physico-Chemical Properties of Suger Beet Chromatin" Alex. Science Exchange J. 4(32),

Sharuti Rathore, Narender Singh and S.K. Singh (2014): Influence of $\mathrm{NaCl}$ on Biochemical Parameters of Two Cultivars of Stevia rebaudiana Regenerated in vitro Journal of Stress Physiology \& Biochemistry, Vol. 10 No. 2 2014, pp. 287-296 ISSN 1997-0838.

Shaw, C.R. (1969): Isozymes classification frequency and significance. International review of cytology. 25:297332.

Sherif F.K, (1999): Effects of salinity stress on root growth, nutrient uptake, and nutrient influx of wheat. Alex. Science Exchange J. vol.20 pp.169-179.

Sherif F.K, M.M. Raslan, F.Z .El-Sammak ,( 2007):Effect of Gamma Radiation on Some Morphological and Biochemical Characters of Tagetes Erecta Grown in Saline Soil. Alex. Science Exchange J. vol.28 issue.2,pp.54.

Weining, S. and P.Landgridge (1991). Identification and mapping of polymorphism in cereals based on polymerase chain reaction . theor.Appl.Genet., 82: 209-216.

Weising, K.;. Nybom; K.Wolff and W.Meyer (1995).DNA Fingerprinting in Plants and Fungi. (CRC Press, Boca Raton, FL).

Williams, J.G.K;A.R.Kubelik; K.J.Livak; J.A.Rafalski and S.V Tingey (1990). Dna polymorphism amplified by arbitrary primers are useful as genetic markers. nuclice acide Res ., 18:6531-6535. 


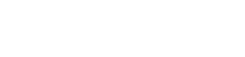

\section{المشابهات الانزيميه للبيروكسينيز ومحتوي البرولين وعلافته بتحلل الملوحه في نبلت الاستفيا}

\section{الميره خطلب}

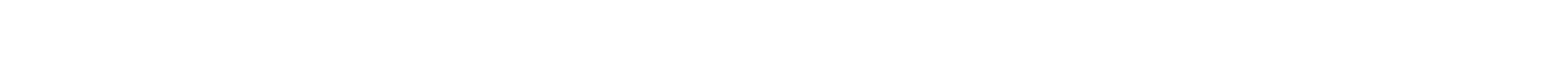

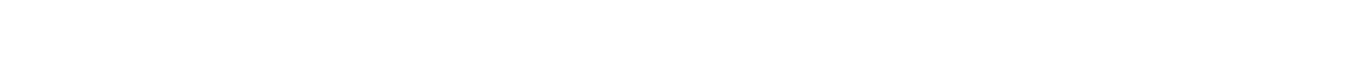

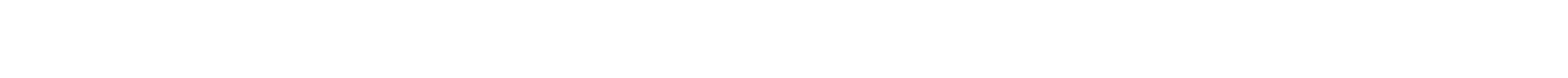

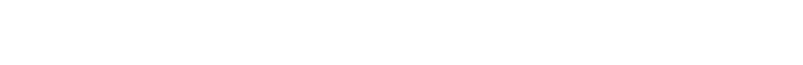

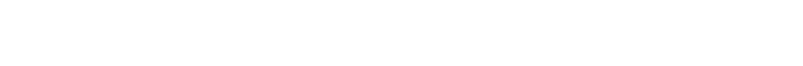

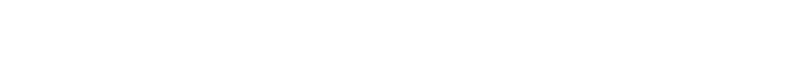
الملوحه. ويوصي البهث الحالي بأن لمتخدلم المشابهات

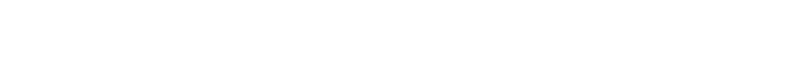

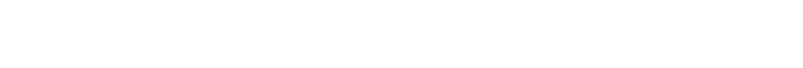
تحمل الملوحيه والبفل في النبات. وكذك محتوي الحمض الاميني البرولين في برنلمج التربيه التربيه

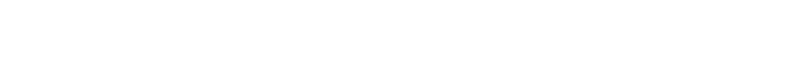

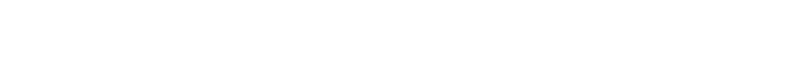

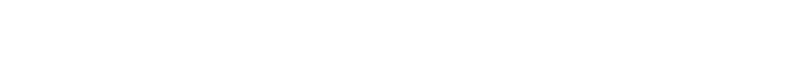

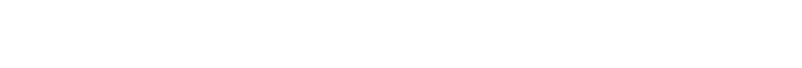

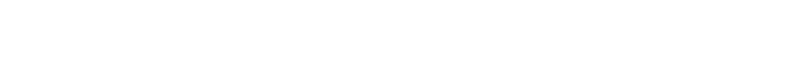
الاوراق من الحمض الاميني برولين قلب المعلمله وكذك التكالي 